\title{
Perancangan Alat Pompa Air Dengan Sistem Penggerak Rendam Menggunakan Motor Listrik
}

\author{
Rahmadsyah $^{1}$, Moraida Hasanah ${ }^{2}$ \\ ${ }^{1,2}$ Program Studi Teknik Mesin \\ ${ }^{1,2}$ Fakultas Teknik Universitas Asahan \\ ${ }^{1,2} \mathrm{Jl}$. Jend Ahmad Yani, Kisaran, Sumatera Utara, Indonesia, 21224 \\ Email: syahuna10@gmail.com¹, moraidahasanah@yahoo.com²
}

\begin{abstract}
Abstrak: Pump merupakan alat pengisap cairan dimana fungsinya dapat mengalirkan suatu cairan dari suatu daerah yang bertekanan kecil menuju ke daerah bertekanan besar. Pompa Submersible (pompa benam) salah satu jenis pump dimana sistem kerjanya diletakkan di kedalam air yang penuh, pump rusak bila air tidak dalam kondisi penuh. Pump jenis seperti ini harus memiliki ketinggian air minumum supaya kerja pump dapat beroperasi secara baik, serta umur dari pump bisa bertahan lama. Pump benam merupakan salah satu tipe dari pump centrifugal. Pump centrifugal memiliki cara beroperasinya perubahan dari kecepatan cairan selanjutnya berubah menjadi bergerak sedinamis mungkin melalui baling - baling tersebut mengalami putaran didalam rumah pump.
\end{abstract}

\section{Kata kunci: Pompa ,Air, Sentrifugal, Rendam}

\begin{abstract}
The pump is a liquid suction device where its function is to drain a liquid from an area of small pressure to an area of large pressure. Submersible pump (submersible pump) is a type of pump where the work system is placed in full water, the pump is damaged if the water is not in full condition. This type of pump must have a drinking water level so that the pump can operate properly, and the life of the pump can last a long time. The submersible pump is one type of centrifugal pump. The centrifugal pump has a way of operating, the change from the fluid velocity then changes to moving as dynamically as possible through the vanes experiencing rotation in the pump housing.
\end{abstract}

\section{Keyword: Pump, Water, Centrifugal, Immerse}

Suatu Unsur bisa diartikan suatu yang memiliki sejumlah nilai besar benda serta mampu menempati satu lingkungan.Unsur benda cair dapat berjalan dari pressure high ke wilayah yang kecil serimaa mengikuti arah tarik bumi. Pada aliran fluida tersebut diperlukan alat pump.. Pump merupakan alat dimana fungsinya mengalirkan suatu fluida cari dari daerah yang satu ke daerah yang lainnya, dibantu melalui suatu pipa dimana ditambahkan usaha pada unsur fluida cair yang akan dialirin. Memiliki beda Pressuare pada 2 bagian tersebut yang didapat melalui sautu sistem berputarnya sudu yang menjadikan penerima pada pengisapan hampa udara (Igor J. Karassik dkk.2001). Pump centrifugal salah satu jenis pressure pump dinamika dimana prosesnya merobah tenaga bergerak ke tenaga sistem tenaga fluida dilakukan secara centrifugal(Sularso, Haruo Tahara. 2004). Mekanisme kerjanya dari pump centrifugal dimana digerakkan oleh sebuah eletromotor, power dari eletromotor ini akan dialirkan ke shaft agar dapat memutar baling -baling yang terpasang di shaft tersebut. Unsur cair yang berada pada baling - baling segera berputar akibat dari dorongan sudu.

Pompa air rendam merupakan salah satu water pump dimana operasional kerjanya dengan manfaatkan gaya centrifugal yaitu perubahan dari tenaga pergerekan cairan ke tenaga potensial dimana pergerakannya menuju permukaan melewati sudu yang mengalami putaran didalam casing pompa rumah pump maka cairan mengalami dorongan diakibatkan pengaruh dari putaran tadi. Water Pump memiliki manfaat baik dipergunakan pada ruang maupun yang berada diluar ruang. Water Pump jenis ini mampu menangin masalah banjir disekitar lingkungan rumah dikarenakan bisa sangat gampang penggunaannya serta sanggup berenang di air tanpa harus khawatir pada kerusakan elektromotor. Selain itu juga, Water Pump rendam ini juga sanggup dipergunakan pada proses mengisap cairan lupmuran,pada pengairan sawah, saringan kolam serta akuarium.

Keunggulan pump rendam: 1) Keawetan lebih baik, 2) noise lebih kecil, 3) Elektromotor lama mengalami panas, 4) Tidak memiliki kedap pada proses pengispan unsur cairan, 5) Kedap terhadap air yang masuk ke electromotor. Sedangkan aspek Kelemahan pump rendam antara lain: 1) Sulit diperbaiki, 2) Harga pump bisa lebih mahal biar bisa tahan lama. 
Submersible Pump digerakkan oleh elektromotor. Elektromotor memiliki As yang arahnya vertikal dan sudu bergabung di as yang arah dari as tersebut vertikal terhadap baling-baling. Karena kedudukan sudu bergabung dengan as dan juga elektromotor maka jika elemot beroperasi sudu juga mengalami putaran serta cairan yang berada di wadah pengisapan secara otomatis terikut sudu-sudu yang ada di baling - baling tadi. Untuk penahanan cairan yang dihisap pada baling-baling, agar tidak mengalami kebocoran kembali pada wadah isapan cairan tadi akan tertahan pada difuser rendah dimana terletak pada bagian dasar dari pump. Cairan yang telah terisap tersebut akan berada di rumah elemot dimana fungsinya supaya eletromotor dingin sebelum mengalir pada proses pembuangan.

\section{METODE}

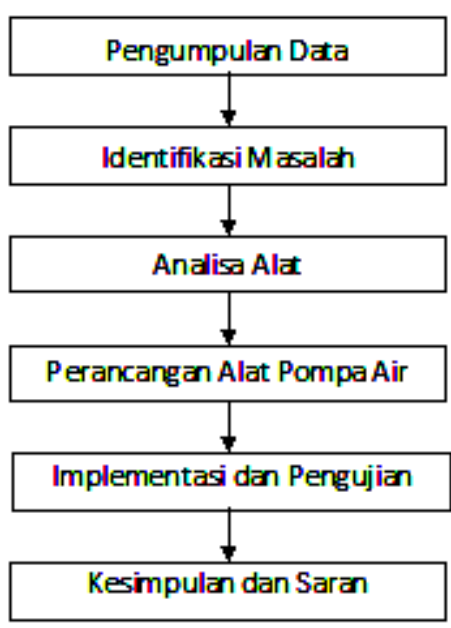

Gambar 1. Alur Penelitian

\section{Desain Penelitian}

\section{Rancang Alat}

Alat itu adalah suatu gambar untuk penyelesaian yang akan dihasilkan, maka alat yang sudah pernah dibuat, bisa diketahui sertadapat gambaran dari hasil proses pengerjaannya. sehingga penelit merancang satu alat pompa air dengan metode rendam memakai motor listrik sebagai penggeraknya.

\section{Menetapkan proses masuk}

Membuat alat pompa air system rendam dengan berbagai komponen - komponen pendukung sesuai dengan dimensi tiap - tiap bagian.

\section{Menetapakan proses keluar}

Keluaran sistem yang diharapkan adalah menjadi alat pompa air sistem rendam yang dapat dipergunakan pada keperluan kehidupan

\section{Penerapan dan Uji alat}

Penerapan sistem

Proses selanjutnya dalam pelaksanaan rancang alat ini dengan melaksanakan penerapan pada sistem alat yang sudah dibuat. Penerapan sistem ini peneliti buat satu prototipe alat pompa air sistem rendam.

\section{Uji Sistem}

Proses selanjutnya adalah proses pengujian alat pompa telah selesai dikerjakan. Pengujian alat pompa bertujuan untuk melihat kinerja dari alat tadi, apa sesuai pada spesifikasi yang telah ada serta sesuai pada yang diinginkan. Lalu 
hasilnya alat pompa air sistem rendam tersebut dapat memindahkan air.

\section{HASIL}

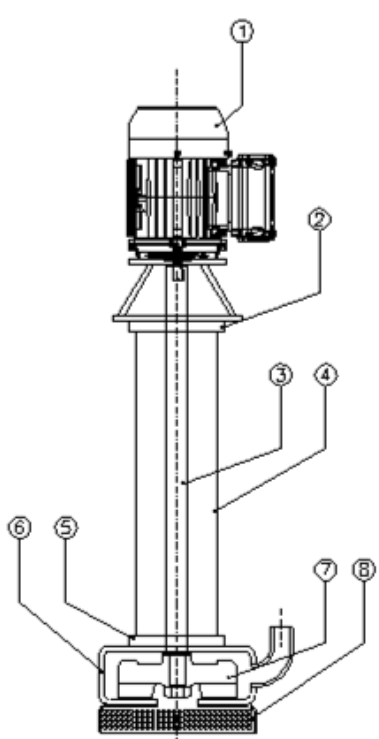

Gambar 2 .Rancangan alat pompa

Keterangan Gambar : 1) Motor Listrik, 2) Bearing, 3) Poros, 4) Pipa, 5) Bearing, 6) Rumah Pompa, 7) Impeller, 8) Saringan

Impeller dapat merubah energi gerak pada pump diubah menjadi usaha kinetis dari fluida yang akan diisap tiap berkala. impeller dibuat dengan proses pembubuatan dan proses pengelesan. Diamater impeller 4 inchi dengan bahan baja karbon sedang. Impeller memiliki 6 sudu dibaut dari bahan plat strip $3 \mathrm{~mm}$.

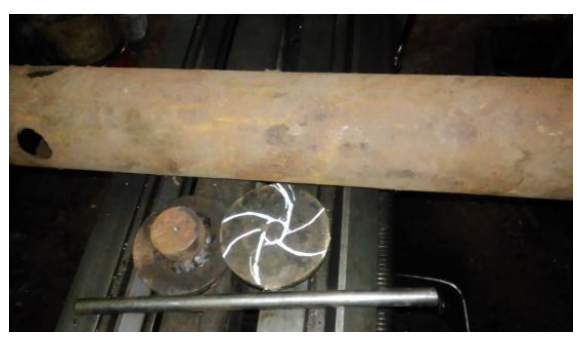

Gambar 3. Impeller pompa air

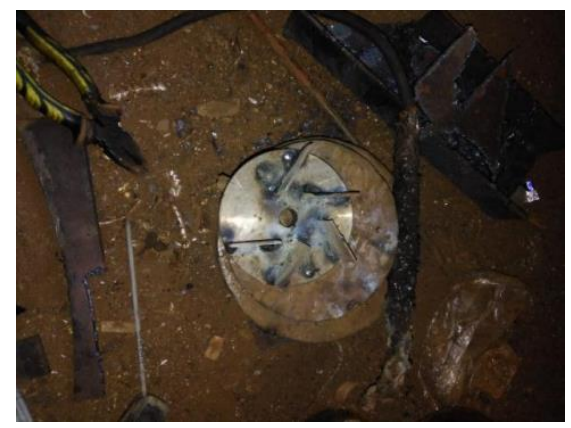

Gambar 4. Proses pembuatan impller dilas 
Cover Bearing tempat kedudukan bearing. cover bearing dibuat dengan proses pembubutan. Ukuran cover bearing 3,5 inchi terbuat dari bahan plat baja $12 \mathrm{~mm}$.

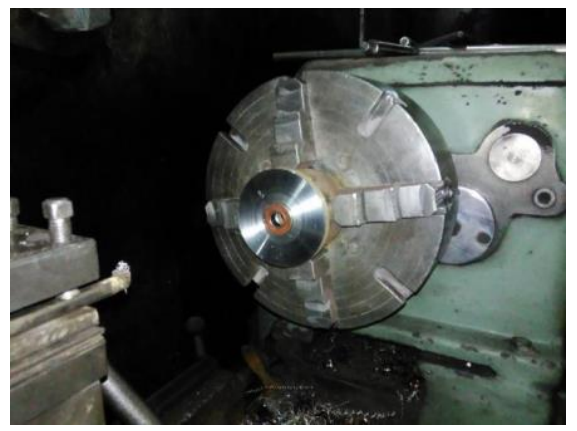

Gambar 5. cover bearing pembubutan.

Rumah oil seal untuk tempat diletakan seal agar tidak terjadi kebocaran. rumah oil seal dibuat dengan proses

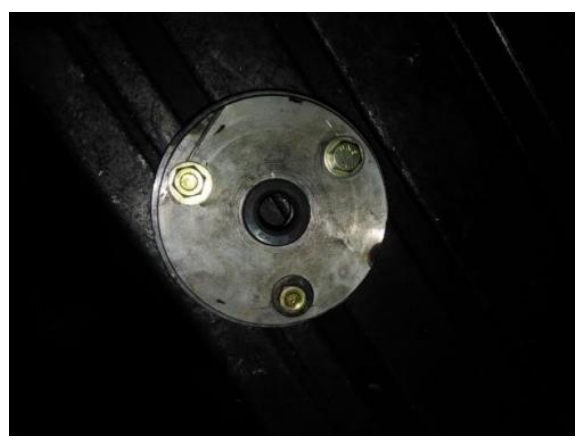

Gambar 6. rumah oil seal

Bodi pompa. bodi pompa merupakan bagian dari pompa yang dirancang, dimana bodi pompa ini berfungsi sebagai tempat pompa. proses pembuatan dari bodi pompa dengan dibubut dan bahan yang dipakai pipa besi ukuran 4 inchi.

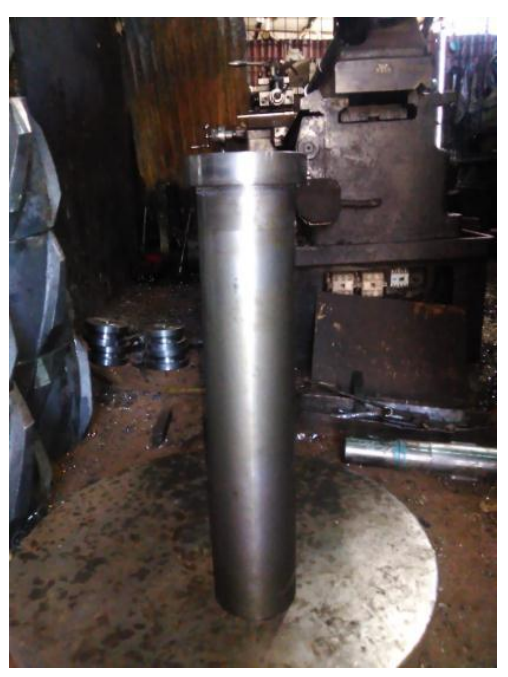

Gambar 7 Bodi pompa

Perancangan Alat Pompa Air Dengan Sistem Penggerak Rendam ........ 
JURNAL TEKNIK MESIN DAN PEMBELAJARAN, Volume 3, Nomor 2, Desember 2020, Halaman: $92-98$

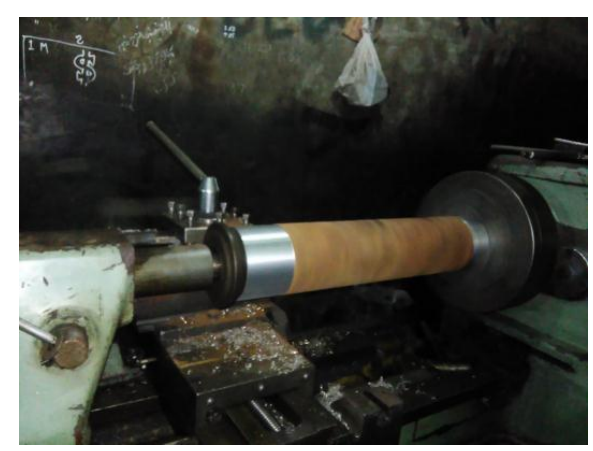

Gambar. 8 Bodi pompa dibubut

Alat pompa air sistem rendam yang sudah selesai dkerjakan

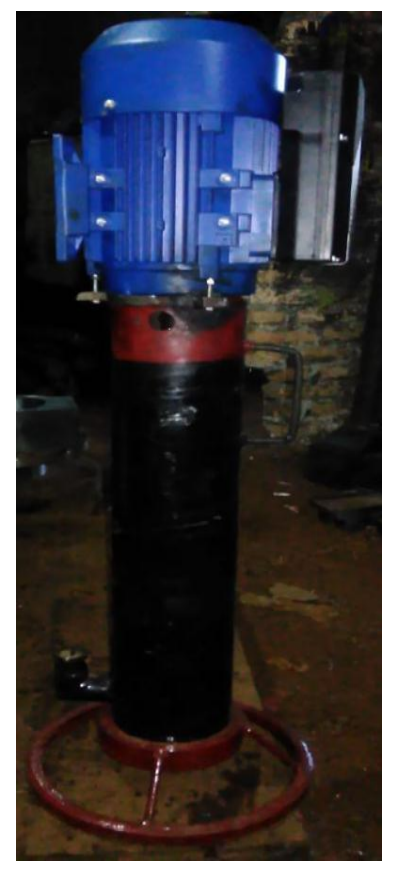

Gambar 9 Pompa air sistem rendam

\section{PEMBAHASAN}

Pada Proses pengujian pada alat pompa air sistem rendam ini fluida yang dipergunakan adalah fluida cair yaitu air. Pengujian ini dilaksanakan melihat tingkat kemampuan dari alat pompa air sistem rendam yang sudah dirancang apakah dapar bekerja sesuai yang diharapakan.Alat pompa air sistem rendam ini menggunakan motor listrik sebagai penggeraknya. motor penggerak akan menggerakkan impller dimana fluida(air) akan terisap ke atas. Fluida (air) akan terisap keluar. Fluida (air) yang keluar dari pompa deras. 


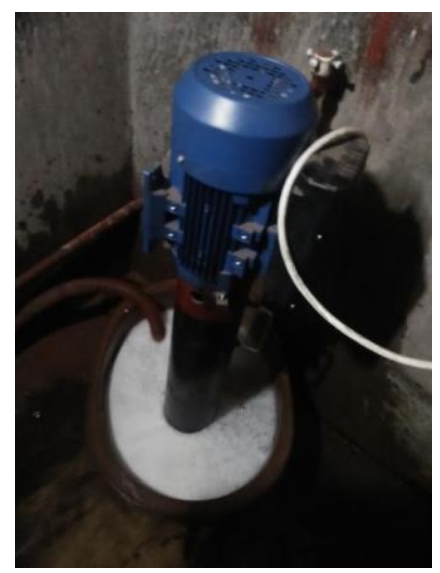

Gambar 10. Proses Pengisian bak penampungan air
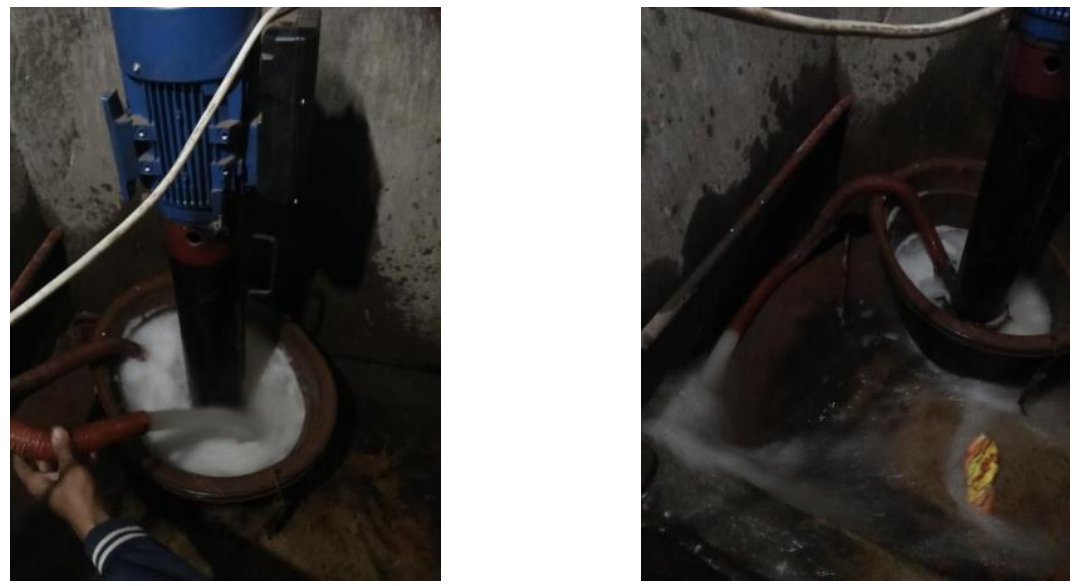

Gambar. 10 Proses pengujian alat pompa air sistem rendam

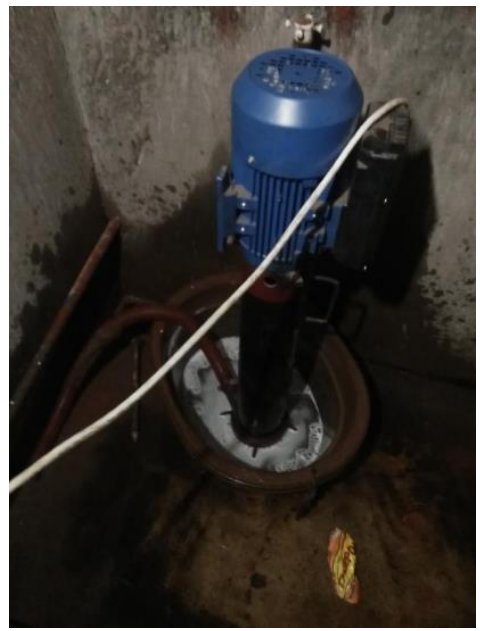

Gambar 11. Bak penampungan sudah kosong

Perancangan Alat Pompa Air Dengan Sistem Penggerak Rendam ........ 


\section{PENUTUP}

Dari Hasil perancangan dan pengujian alat pompa air sistem rendam ini dapat disimpulkan sebagai berikut yaitu (1) Pompa rendam adalah salah satu jenis pompa sentrifugal (2) Kapasitas air mempengaruhi kinerja dari alat pompa air sistem rendam (3) Pemasangan impeller mempengaruhi kinerja dari tekanan isap alat pompa.

\section{OPSIONAL}

Peneliti memberikan apresiasi yang sebesar - besarnya pada Dikti untuk Anggaran PDP Tahun 2020 dengan jumlah anggaran yang diberikan RP.19.932.001 pada SK. Nomor 298/LL1/PG/2020.

\section{DAFTAR RUJUKAN}

Bruce R. Munson, Donald F. Young, Theodore H. Okiishi. 2002. Mekanika Fluida Keluaran Satu. Penerbit Erlangga. Jakarta. Dietzel, F.1992, Turbin Pompa dan Kompresor, Penerbit Erlangga, Jakarta

Igor J. Karassik, Joseph P. Messina, Paul Cooper, Charles C. Heald.2001, Pump Handbook, Third Edition, McGraw-Hill Book Co, New York.

Lemigas. 2000. Dasar-Dasar Pompa Positive Displacement dan Centrifugal, Lemigas, Jakarta.

Sularso, Haruo Tahara. 2004, Pompa Dan Kompresor, Cetakan Ketujuh, Pradnya Paramita, Jakarta. Pudjanarsa A, Nursuhud Djati. 2008, Mesin Konversi Energi, C V . Andi, Yogyakarta 